\title{
Assessing academic contributions in landscape architecture
}

\author{
Lee-Anne S. Milburn ${ }^{\mathrm{a} *}$, Robert D. Brown ${ }^{\mathrm{b}}$, Susan J. Mulley ${ }^{\mathrm{a}}$, Stewart G. Hilts ${ }^{\mathrm{c}}$ \\ a Department of Landscape Architecture, Mississippi State University, Box 9725, Mississippi State, MS 39762-9725, USA \\ b School of Environmental Design and Rural Development, University of Guelph, Guelph, Ont., Canada NIG 2W1 \\ c Department of Land Resource Science, University of Guelph, Guelph, Ont., Canada N1G 2WI \\ *Corresponding Author
}

NOTICE: This is the authors' version of a work that was accepted for publication in LANDSCAPE AND URBAN PLANNING Changes resulting from the publishing process, such as peer review, editing, corrections, structural formatting, and other quality control mechanisms, may not be reflected in this document. Changes may have been made to this work since it was submitted for publication. A definitive version was subsequently published in LANDSCAPE AND URBAN PLANNING, VOLUME 64, 2003, pages 119-129. PII: S0169-2046(02)00204-9. If you refer to this work please cite the published version. 


\begin{abstract}
There is an increasing demand for research in landscape architecture to inform design decision making. The role of the faculty in departments of landscape architecture has changed from one of educating professionals to one that includes contributing to research and to the development of the discipline. This paper develops a framework for assessing the contribution of faculty in landscape architecture. It proposes a reconsideration of Boyer's [Scholarship Reconsidered: Priorities of the Professoriate, The Carnegie Foundation for the Advancement of Teaching, Princeton, NJ, 1990; Building Community: A New Future for Architecture Education and Practice, The Carnegie Foundation for the Advancement of Teaching, Princeton, NJ, 1996] scholarship framework by clarifying the definition of scholarship as research, and identifies research, teaching and service as contributions to academe. Furthermore, it proposes that design, teaching and service can be either topics of research or products of research, but are not, by definition, research. This framework clarifies the issue of how design fits into the academic environment, and provides concrete guidelines for the assessment of both traditional research activities and non-traditional activities such as design.

Boyer [Scholarship Reconsidered: Priorities of the Professoriate, The Carnegie Foundation for the Advancement of Teaching, Princeton, NJ, 1990; Building Community: A New Future for Architecture Education and Practice, The Carnegie Foundation for the Advancement of Teaching, Princeton, NJ, 1996] identifies six main criteria that should be considered in the review of scholarship: clear goals; adequate preparation; appropriate methods; significant results; effective communication; and reflective critique. These criteria have been adapted in light of the argument developed by this paper for peer review, new or substantially improved insight, and universal accessibility as the overarching criteria for contributions to academe. The result is a set of detailed checklists for the assessment of published research and of other contributions to academe (such as teaching and design), which are communicated through other vehicles.
\end{abstract}

Keywords: assessment, scholarship, research, design, teaching, outreach 


\section{Introduction}

The profession of landscape architecture is defined by the two paradigms which emerged after World War I: conservation/planning and aesthetics (McHarg, 1997). Over time this division has reinforced a perceived dichotomy between research and design, and between rigorous academic pursuits and practical professional skills. Traditionally, the academic practice of landscape architecture has focussed on the preparation of students to enter and participate in the profession. Increasingly, however, university administrators are demanding that landscape architecture faculty participate in research and scholarly activities. This is complementary to the generally increasing demand for research from the public and private sectors to provide justification for design and planning decisions (Chenoweth and Chidister, 1983; Nassauer, 1985; Harris, 1995; Innes, 1996). Consequently, the role of the academic is changing from one focussed on professional education, to one that includes contributing to research and to the development of the discipline.

Landscape architecture does not fit the traditional model of an academic department. In fact, the entry of design professions into the university system:

... was not, as other disciplines, the product of a long transformation of academic departments out of the traditions of medieval and modern scholarship, from rhetoric to philology to "disciplines" as we know them today, but generally lock, stock and barrel, as pre-formed professional entities, the old academic ateliers ... transplanted so to speak onto alien ground. (Vidler, 1992, pp. 130-131)

Despite this lack of formative academic tradition in the design professions, the academic community expects landscape architecture to function as an academic discipline (Dagenhart and Sawicki, 1992). As such, the academy looks at teaching and research, and particularly publication, as the contribution of faculty to the profession.

The nature of landscape architecture as an anthropocentric design profession inherently supports the use of human experience and anecdotes over rigorous research (Rosenberg, 1986; Thompson, 1998). As a result, landscape architecture and related professions have been struggling to resolve the criteria of academic research with a discipline traditionally based on design, professional knowledge, 'intrinsic' understanding, and practical application. While some educators welcome research into the academic practice of landscape architecture, Selman argues that ". . . others fear the ways in which it might diminish practical studio-based teaching, which has been the designers' traditional forte" (Selman, 1995, p. 49). The current battle to establish design as a viable form of research as addressed by Benson (1998), Selman (1998), Thwaites (1998), Armstrong (1999), and Bowring (1999), can be interpreted as the result of this longstanding battle to reconcile these forms of traditional knowledge with the requirements of rigorous scholarly research. This struggle is at the heart of the current division in the profession between design- and research-oriented academics. Is design research? If not, what then is design's relationship to research?

Landscape architecture faculty further the goals of the university through research, teaching, and service, ${ }^{1}$ and support the goals of the profession by producing thoughtful, reflective practitioners who value learning, critique, and altruistic service as intrinsic components of a strong, dynamic profession. Design is central to landscape architecture, and research related to design must achieve both rigor and flexibility to have both credibility in the academy, and applicability to the profession.

In general, the role of the academy is to:

- question the status quo;

- improve and diffuse available information;

- authenticate the substance of information;

- control quality; and

- establish norms for scholarship (Zuckerman and Merton, 1971).

Viewed from this perspective, the advancement of knowledge through research, teaching, and service is primarily through questioning existing information or assumptions, improving the knowledge which is available, verifying accuracy and quality, and communicating with the larger community. This paper defines research and design, describes their structures, and examines the relationship between the two activities. It attempts to identify opportunities for the assessment of design and other activities as academic contributions. A framework is proposed

\footnotetext{
${ }^{1}$ Or community interactions and administration.
} 
to clarify the relationship between research and design which suggests a role for design in scholarship. Several case studies are provided to illustrate the potential application of the framework.

\section{Defining and assessing research in landscape architecture}

Recent contributions on scholarship (Boyer, 1990; Glassick et al., 1997; Boyer and Mitgang, 1996) have expanded the definition of scholarship beyond that of research. The framework of the scholarships of 'discovery', integration', 'application', and 'teaching' have provided an important recognition of the value of practice and teaching as contributions to the academic community (Table 1). The 'scholarship of integration' allowed for the recognition of inter-, multi-, and transdisciplinary work at a time when these areas were struggling for validation. It further recognized 'qualitative' and 'theoretical' research as valuable, though different in method and methodology from the traditional 'scientific' approach of hypothesis generation and laboratory testing. This framework has, however, served to encourage many educators to confuse teaching, service, and research. Chenoweth argues that, in landscape architecture, we have attempted to increase research by "simply defining whatever one does as research, perhaps inserting words such as 'action' or 'design' or 'holistic' before 'research' " (Chenoweth, 1992, p. 47). As such, Boyer's scholarships of integration and application have become defined variously in landscape architecture as research on design or practice, or, more often, and incorrectly, design or practice as research (see Benson (1998),

Selman (1998), and Thwaites (1998) for discussions of design as research). This paper redefines Boyer's (Boyer, 1990; Boyer and Mitgang, 1996) scholarship framework as contributions to academe, which are identified as research, teaching, and service (Fig. 1). At the center of the problem is the definition of research.

As noted by Riley:

The term research is used too broadly, surely. At one extreme, most of us recognize a narrow model of research from the experimental or laboratory sciences: the posing of a hypothesis, the testing itself, conclusions, modification of the hypothesis, and so on. At the other extreme, our undergraduate design students, flipping through magazines the first week of a design project, are "doing their library research".

(Riley, 1990, p. 47) This broad definition of research encourages confusion in the discipline related not only to the conduct of research and its assessment, but also to the relationship between research and design.

As Dyck noted:

"positivist disciplinary science is necessary, but not sufficient, as a basis for this design process" (Dyck, 1994, p. 145). Thus, unlike the traditional definitions of research as “. . . systematic, controlled, empirical, and critical ..." (Kerlinger, 1986, p. 10), this paper proposes a definition of research which is inclusive of nonexperimental data collection methods and qualitative forms of data analysis, as well as interdisciplinary integrative approaches.

The British Research Assessment Exercise divided research into three categories:

- Basic research is experimental or theoretical work undertaken primarily to acquire new knowledge of the underlying foundation of phenomena and observable facts, without any particular application or use in view.

- Strategic research is applied research in a subject area that has not yet advanced to the stage where eventual applications can be clearly specified.

- Applied research is work undertaken in order to acquire new knowledge. It is, however, directed primarily toward practical aims or objectives (Universities Funding Council, 1992, as quoted in Patrick and Stanley (1996)).

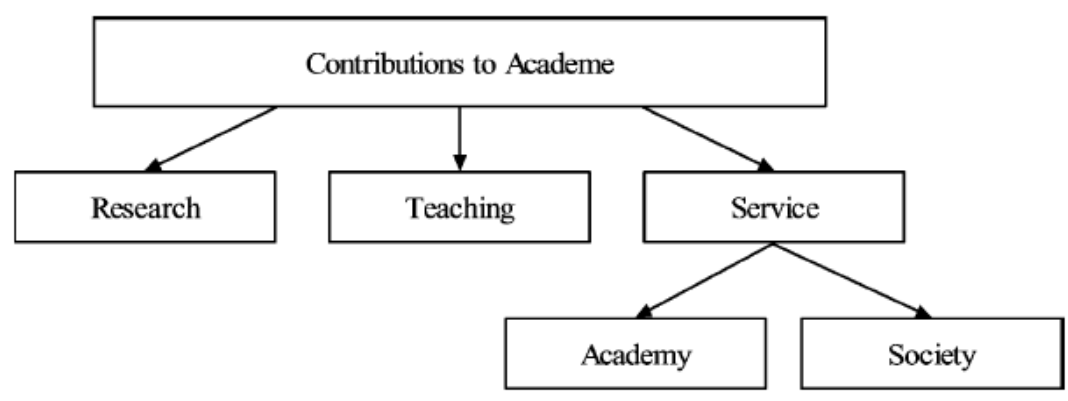

Fig. 1. Contributions to academe. 
All three types of research are rigorous endeavors which attempt, through generally accepted methods of data collection and analysis, to reduce data into a compelling, authentic, and meaningful statement that extends our understanding of a given state, issue, perspective, or action, and which is critically peer reviewed, universally accessible, and provides a new or substantially improved insight. This definition of research supports design as a topic of research but excludes design as a research method.

The primary tools for establishing the quality of a faculty member's research contribution are subjective evaluation (peer review), number of publications, citations, and number and value of grants and contracts awarded (Rudd, 1988). Notably, three of the four criteria listed are measures of quantity. Peer review is the only tool currently in use for authenticating the substance and assessing the potential contribution of research (Zuckerman and Merton, 1971). In assessing the contribution of research to academe, critical peer evaluation is joined by universal accessibility through communication, and contribution to the knowledge-base of a discipline.

\section{Defining and assessing design in landscape architecture}

The argument that design is a form of research has become popular in architecture and landscape architecture as a way to access research funding and grants, and to fulfil requirements for yearly contract reviews and promotions (Baron, 1981; Nassauer, 1985; Schön, 1988; Brink, 1997; Benson, 1998; Selman, 1998; Thwaites, 1998). This motivation springs from many sources including pressure in educational institutions to produce research in professional programs (Chenoweth and Chidister, 1983; McLaughlin, 1991) and confusion over what constitutes research (Chenoweth and Chidister, 1983; Palmer et al., 1984; Chenoweth, 1992; Palmer and Smardon as quoted in Riley, 1995; LaGro, 1999). Though this paper argues that design is not research, it does recognize that the design and research processes have much in common. Steinitz (1995) has argued that design is both a verb and a noun; it is both the process of conceiving and planning, and a plan or scheme of elements which have been created and arranged. Research, as well, is often defined as both a verb and a noun (Riley, 1990). The current prevalent argument seems to believe that the processes of research and design are the same, and therefore the products are equivalent. The relationship between design, teaching, service ${ }^{2}$, and research is, however, more complex than is indicated by this simplistic understanding of research.

Design and research are similar in process and the intent of the product, but differ in method and general applicability. As such, design and traditional research both qualify as contributions to academe, but require different criteria for assessment. A design must have the following attributes to be considered a contribution to academe:

- quality;

- thought;

- originality;

- significance;

- technical merit;

- evidence of a vision;

- excellent collaboration with practitioners;

- have received regional, national or international awards or honors;

- no fiscal reward; ${ }^{3}$

- written documentation; and

- universal accessibility (based on Midwinter, 1997).

\footnotetext{
${ }^{2}$ For the purposes of this paper, contributions to practice are classified as service.

${ }^{3}$ Payment for design is inherently different than payment for research through external granting bodies. While external research grants may pay for research time, in fact, grants pay the institution for release time for faculty engaged in research on a specific research project. Nine-month faculty appointments in landscape architecture stem from a summer private practice model, and serve to confound both faculty and administration as to the structure of dispersal of research grant monies. Disciplines with traditional 12-month research and teaching faculty appointments do not suffer from this confusion.
} 


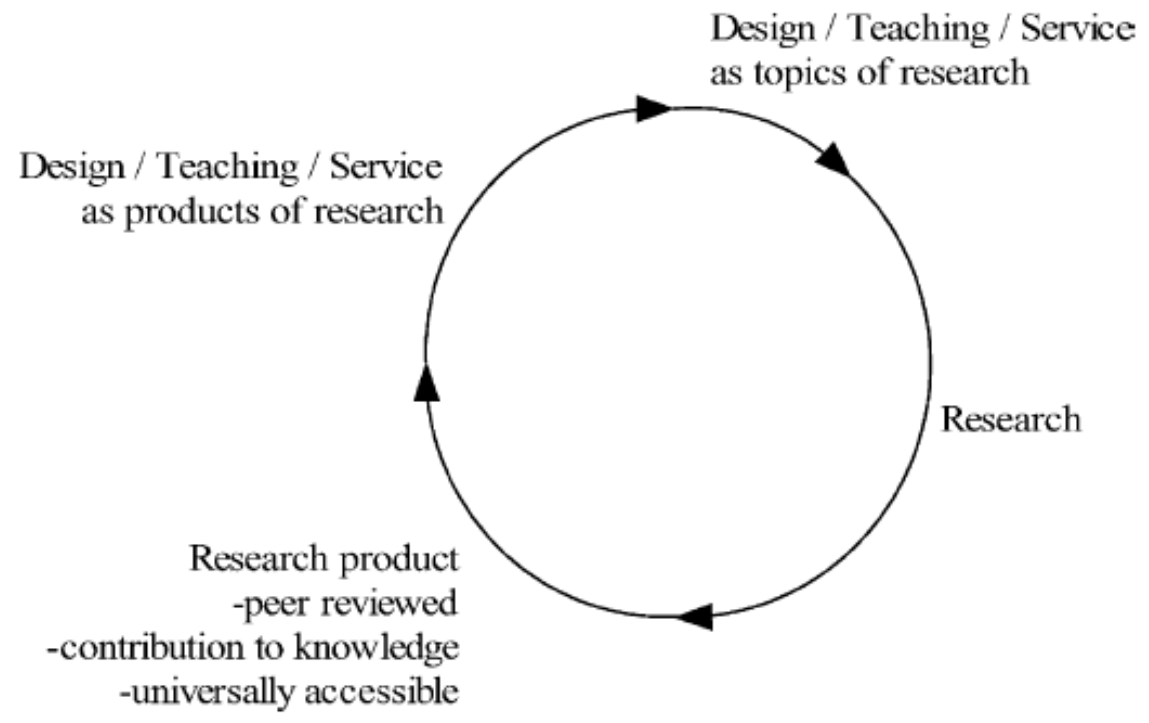

Fig. 2. Research cycle.

Design can also have a dynamic relationship to research through the creation and use of design standards or by using research results to inform the design process. For example, the process of collecting site data for inventory purposes, examining precedents, reviewing research in the library, and conducting a site analysis and synthesis is invaluable to design, but does not fulfil the criteria for a research contribution.

'Design, and by extension teaching and service, can be either a topic of research or a product of research, but are not, by definition, research. In other words, design is located at the beginning of the research process as the incentive for, or topic of, research, or at the end of the research process as an application of the insights and understandings acquired as a result of the study (Fig. 2). Thus, there can be research into design, research as a response to design, or research leading to or informing design. Within the research process the researcher can study the design process itself, report on a particular case, critically reflect on years of experience, or analyze prior work, all as topics of research. Design can occur after research through the application of design standards informed by rigorously conducted, peer reviewed, universally accessible research. The design itself, however, is not research. Other authors have also made this distinction. LaGro, for example, argues:

Certainly, questions are posed and answered in the design process . . . design theory, informed by criticism and research . . . can help the designer draw an informed, yet personal response to this question. The processes of design . . . involves the reasoned application of ideas and knowledge derived from different sources, including critical inquiry, criticism and research.

(LaGro, 1999, pp. 181-182)

The information which informs the design is research if it is assessed according to established norms for scholarship. The same framework applies to teaching and service. For example, the researcher can examine the processes of design, teaching, or service, the history of design, teaching, or service, or the results of design, teaching, or service. Design, teaching, and service are irreplaceable contributions to academe which should be assessed on their own merits. However, the act of design, teaching, or service, and the products of design, teaching, or service, are not, in and of themselves, research.

To further clarify this distinction, for example, a research project involving the examination of a question related to human aesthetics, comfort and safety can have as its ultimate product a design, but it is the research which is peer reviewed. The research project could examine the issue of human thermal comfort in urban plazas (What factors impact upon the individual's perceived comfort in certain urban environments?), from which design guidelines could be produced, ${ }^{4}$ which could inform the design and construction of an urban plaza. Research could then be produced which assesses the plaza's success at impacting upon human thermal comfort through a postoccupancy evaluation. Similarly, results of research on the topic of teaching can be applied to teaching, but teaching

\footnotetext{
${ }^{4}$ See Cooper Marcus and Francis (1998) for examples of research which generates design guidelines.
} 
itself is not research. ${ }^{5}$ Design, teaching, and service can be products of research as well as topics. A research project can be undertaken which impacts on the academy by advancing the practice of teaching, or providing insights to the profession through a consultancy report. The research itself, peer reviewed, universally accessible, and providing a new or substantially improved insight, is the basis of a further application or communication of the results in a more easily applied format. Design, teaching and service can be topics of research, but are not themselves methods of research. In the end, design, teaching and service use research to recognize the connection to the people, places, and issues located outside the boundaries of the academy. Ultimately, society should benefit from knowledge generated by the academy.

\subsection{Example 1: An issue in teaching becomes the topic of research}

Take the example of an alumni survey that revealed a need for information on how to integrate recent research results on brownfield restoration into the landscape architectural design process. An educator might decide to develop instructional support materials to resolve this shortcoming in the curriculum. Calling on their own design experience and sharing it with students would be a good start, but would not be considered a scholarly activity. One way this educator could create a contribution to academe would involve a critical review of the literature, identification of a defined goal, and the evaluation, synthesis and integration of the relevant literature.

The creation of a framework or theory for understanding the issue in light of existing research and theory is a contribution to academe. This work, however, can lead to a further contribution through the exploration and testing of the usefulness of the resultant framework. This could involve:

- undertaking a series of interviews or the administration of a survey;

- careful analysis and interpretation of the data; and

- the preparation of a manuscript for submission to a refereed journal and/or presentation at an academic conference.

The resulting insights could also be communicated more broadly through an article in a popular magazine, the development of teaching materials, and modification of teaching practice (teaching as a product of research). The introduction of this material into the curriculum might offer the further opportunity for an experiment to determine whether or not the material had the desired effect (teaching as a topic of research). This process could result in products that benefit students and practitioners through improved ability to communicate with clients, employers, and employees.

\subsection{Example 2: An issue in design becomes the topic of research}

Private consultations can provide a vehicle for an academic contribution as well. The design of an interpretative trail in an environment where Lyme disease is a concern could be an example of this approach. The investigator could create a contribution to academe through a critical review of the literature, the identification of a defined goal (in this case, minimizing the potential for trail users to contract Lyme disease), and the evaluation, synthesis and integration of the relevant literature.

The creation of a framework or theory for understanding the issue in light of existing research and theory is a contribution to academe. Ward (1999) for example, examined this issue, and created a decision-tree framework that could be useful in determining how to proceed with new developments. This work, however, can lead to a further contribution through the exploration and testing of the framework. This framework could then be applied to the design commission (design as a product of research), with detailed design and construction producing a product which can then be assessed for its ability to minimize user contraction of Lyme disease (design as a topic of research). The results of both the integration and the application could be written as an article for a refereed journal, and presented at an academic and/or professional conference. The results could also be communicated through professional bulletins, newsletters, and extension communications, all of which would benefit the profession, the public, and the investigator.

\footnotetext{
${ }^{5}$ Feldman (1987) comprehensively examines the relationship between research and teaching and identifies a small but positive relationship between research productivity and teaching effectiveness. Notably, however, he lists an extensive number of possible common causes which challenge the causal link. This would suggest that teaching and research have different time, effort, and personality requirements, impacts, contexts and conditions, which would support this paper's argument that they should be assessed according to individualized criteria. In fact, Midwinter argues that the "prime benchmark used in teaching assessment is the department's own self assessment" (Midwinter, 1997, p. 67).
} 


\subsection{Example 3: Design as a contribution to academe}

Another example might be the often contentious issue in academic landscape architecture, that of credit for design commissions. Take the example of the design of an accessible play area for children: the project could be a contribution to academe through a critical review of the literature; the identification of a defined goal (in this case, maximizing learning and play opportunities for physically challenged, blind, and deaf children); and the evaluation, synthesis and integration of the relevant literature.

The creation of a framework or theory for understanding the issue in light of existing research and theory is a contribution to academe. This framework could result in design standards to guide the creation of the play area (design as a product of research) through detailed design and construction. If this product is then recognized as an important achievement and a significant contribution through an established professional awards program such as the ASLA Professional Awards, and information on the project is published in a recognized journal or magazine such as Landscape Architecture, it qualifies as a contribution to academe.

\section{Assessing contributions to academe: proposed criteria for scholarship in landscape architecture}

Boyer's (1990) framework did not clearly differentiate excellent teaching or service from teaching or service as a contribution to the academic community (Hutchings and Shulman, 1999). Additionally, Boyer's framework does not specifically address design. There is also an assumption in his framework that quantity of experience provides significant insight. This assumption must be overcome; merely participating in an activity or developing a product many times does not presuppose an insightful or even an accurate understanding. Assessment of quality in addition to quantity is therefore critical.

Contributions to academe must fulfil three key criteria: critical peer review; new or substantially improved insight; and universal accessibility. The first two are issues of quality, the latter of communication. The strongest research, it could be argued, incorporates both an assessment of the issue as a topic, and the creation of a framework which addresses it as a product. In addition, there are at least two points at which the quality of research contributions must be evaluated: during the peer-review process of an article or monograph leading to publication; and during the peer evaluation of a researcher's overall contribution to academe during promotion and tenure decisions.

The assessment of quality is necessarily a peer-based evaluation process especially in highly differentiated and interdisciplinary fields such as landscape architecture because:

... the functional significance of the referee system increases with the growing differentiation of science into arrays and extensive networks of specialities. The more specialised the paper, the fewer there are who can responsibly appraise its worth. But while only a few may be fully competent to assess, many more on the periphery of the subject and in other related fields may find the paper relevant to their work ... [and in fact, it is] others making use of published results in fields tangential to their own who particularly depend upon the referee system. (Zuckerman and Merton, 1971, pp. 98-99)

Without a strong disciplinary background to provide a depth of inquiry upon which to draw, landscape architects are dependent on the referee system to establish confidence in the quality of information used in their own research. Furthermore, the referee system eliminates the need for a constant checking of the results and theories advanced by others, and thereby allows researchers to devote themselves to novel and creative inquiries (Zuckerman and Merton, 1971).

According to Tschumi (1990), research is the mechanism through which professions advance and improve their techniques, and escape the tendency to reflect the prevalent mode of production. Rosenzweig (1999) argues that research can and should take hundreds, if not thousands of hours, and needs to move beyond a discussion of what was done, how it was done, what happened as a result, and how people liked it. The criteria of 'new or substantially improved insight' requires a deeper understanding of the issue or topic under study, a rigorous examination, a careful interpretation of the results, and conclusions of impact or meaning.

Communication is key. Academic contributions must be documented in order to be accessible to the academy and society. According to Magee:

... any criticism . . . or proposed change, or solution to a problem, has to be formulated in language before it can be tested or even discussed; any such proposal becomes an objective proposal. It can be argued about, attacked, defended, used, without reference to the man [or woman] who put it forward. Indeed, this is what happens most of the time with interesting ideas. 
This underlines the enormous importance of objectifying our ideas in language or behavior or works of art. While they are only in our heads they are barely criticizable. (Magee, 1985, p. 72)

Unfortunately, with the exception of Louisiana State University's Critiques of BuiltWorks of Landscape Architecture series, landscape architecture largely lacks a tradition of critical inquiry and critique. In his discussion of the scholarship of teaching, Shulman (1995) identifies the related central features of scholarship as:

1. community property;

2. susceptible to review and evaluation by peers; and

3. amenable to application by others.

Table 2

Criteria for assessing the quality of research for refereed journal publication

\begin{tabular}{|c|c|c|}
\hline 1 & Clear goals & $\begin{array}{l}\text { The study has.... } \\
\text { Clearly defined and articulated objectives based on critical review of scholarly literature } \\
\text { An important and meaningful question that has not yet been completely answered by others }\end{array}$ \\
\hline 2 & Adequate preparation & $\begin{array}{l}\text { The researcher has... } \\
\text { A thorough and critical understanding of the scholarly literature related to the topic } \\
\text { Command of the skills necessary for the conceptualization, conduct, and evaluation of the study }\end{array}$ \\
\hline 3 & Appropriate methods & $\begin{array}{l}\text { The data collection and analysis methods are ... } \\
\text { Appropriate to the study } \\
\text { Applied effectively and correctly }\end{array}$ \\
\hline 4 & Significant results & $\begin{array}{l}\text { The results are... } \\
\text { An achievement of the study objectives } \\
\text { A significant contribution to the field }\end{array}$ \\
\hline 5 & Effective communication & $\begin{array}{l}\text { The product of the study is ... } \\
\text { A communication tool appropriate to the results } \\
\text { Well written and/or demonstrated } \\
\text { Effectively communicated with a suitable style and understandable organization }\end{array}$ \\
\hline 6 & Reflective critique & $\begin{array}{l}\text { The researcher displays ... } \\
\text { A positive response to criticism } \\
\text { An ability to be self-critical of their own work }\end{array}$ \\
\hline
\end{tabular}

These features are dependent on the universal availability and accessibility of the results of research into the topic of teaching. Thus, research is also defined by its mode of communication and dispersion to peers and others in related disciplines. Research is dependent upon dissemination through printed and electronic media and public oral presentations for its acceptance as a contribution to academe.

Research in landscape architecture must provide the connection to design, teaching and service. They are irreplaceable contributions to the academic community which should be assessed according to their own applicable criteria, and validated as the application of research. Boyer (1990) identifies six main criteria that should be considered in the review of research:

- clear goals;

- adequate preparation;

- appropriate methods;

- significant results;

- effective communication; and

- reflective critique (Tables 2 and 3).

These criteria have been revised in light of this paper's argument for peer review, new or substantially improved insight, and universal accessibility. The result is a set of detailed checklists for the assessment of research for publication and the assessment of other contributions to academe, including design, teaching, and service. Table 2 is intended as a checklist for peer review of the general quality of research for publication (which may be on 
design, service or teaching). Table 3 is a checklist for peer review of the quality of research, design, teaching, and service communicated via publication in vehicles other than refereed journals, such as books, manuals, handbooks, teaching materials, and juried design competitions. This table provides criteria specific to the evaluation of design, teaching, and service activities. Contributions to academe which comply with the criteria detailed in Table 2 (for refereed journal publications) or Table 3 (for all other publications) should fulfil the requirements for promotion, merit and tenure assessment. Again, communication and accessibility are key components for research, design, service and teaching. Merely doing is not adequate for assessment. These tables provide frameworks through which design, teaching and service can receive appropriate recognition and reward.

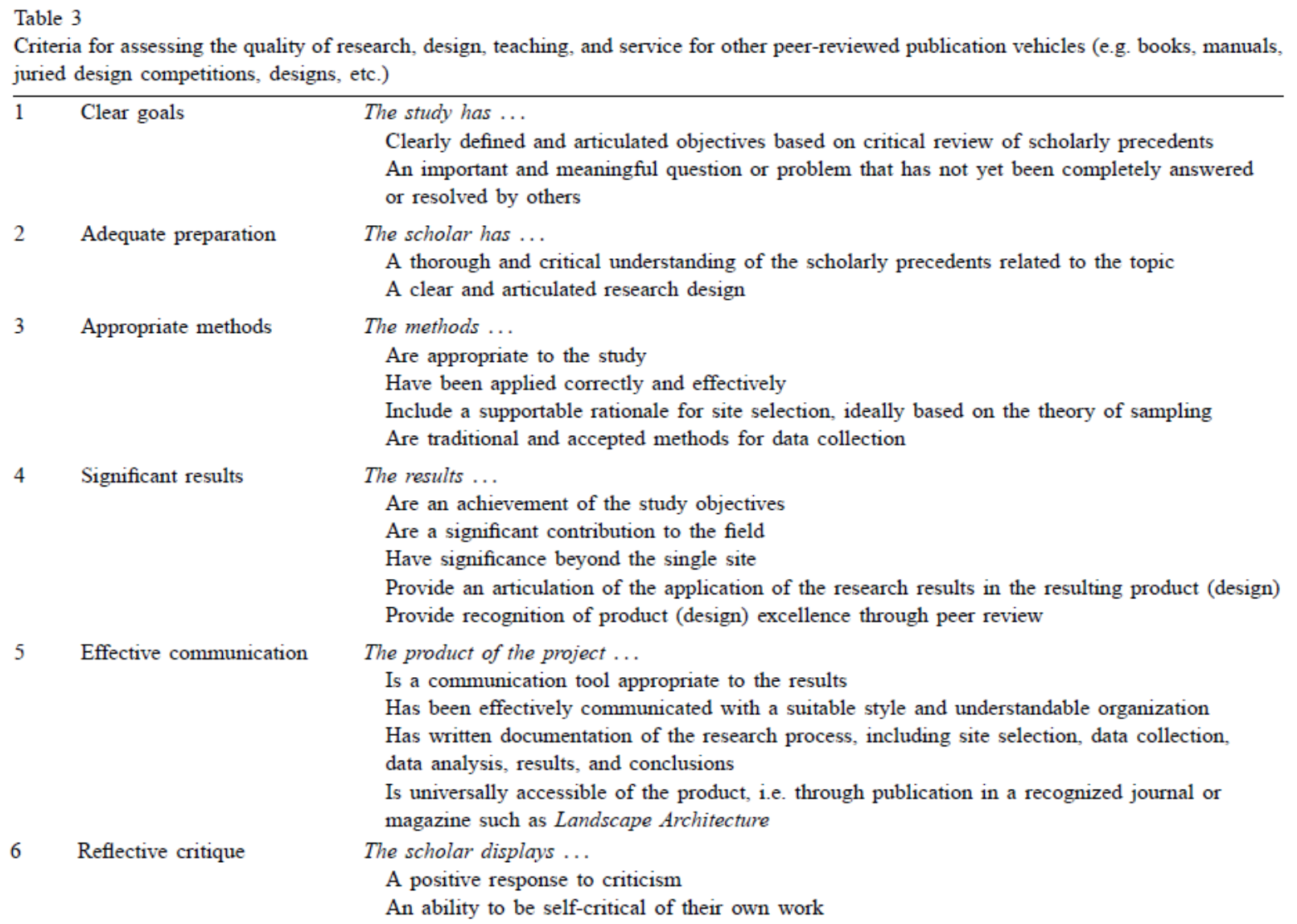

\section{Discussion}

The current popularity of the 'refereed studio' (see Landscape Review series in 1997 and 1999 and Landscape Research series in 1998) as a venue for research does not situate design and teaching within existing research frameworks. This issue is related to the difficulty of locating design and teaching within traditional promotion, merit and tenure criteria. Benson argues that '. . . the shorthand of 'design is research,' [is] glib, trite and simplistic, flying in the face of a mass of evidence to the contrary. I have a feeling that the debate (is there a debate?) is symptomatic of a paucity of research training and culture in landscape architecture" (Benson, 1998, p. 201). In his 1999 article in Landscape Journal, LaGro states that ". . . most faculty members in landscape architecture do not have training in the sciences" (LaGro, 1999, p. 184). This opinion was shared by the respondent to a recent survey of educators in landscape architecture who stated that ". . . Research methods courses were not part of professional education in the early 1960's and research was not valued in our profession until the late 1970's" (Milburn, 1999, p. 167). In fact, the results of that study indicate that while almost $30 \%$ of respondents had taken one or less research methods courses at the undergraduate or graduate level, $70 \%$ had exposure to two or more courses, with an average 
of 4.32 courses per respondent. ${ }^{6}$ As suggested by Steinitz (1998), these surprising results could be contributed to the undergraduate degrees of individuals with first-professional MLA degrees. These results would suggest that the issue is not comfort or skill with research methods, but rather motivation or time.

The proposed framework is valuable for its assessment of the roles of design, teaching, and service within the research process, and its recognition that these academic activities do not, in and of themselves, constitute research. The arguments that 'design is research' or 'teaching is research' do not give credit to the valuable contribution these activities make in their own right. The visual language of design is “. . . subtle, precise, powerful and accessible for rapid perusal, aesthetically and intellectually satisfying" (Edwards, 1987, p. 29), and has a unique and valuable contribution to make to research and practice in landscape architecture. Regardless, we should be concerned ". . . with the ability of the processes in which we are engaged to effectively respond instead of preoccupation with the attributes of the products we produce ..." (Eberhard, 1968, p. 38). As faculty in landscape architecture, we have a responsibility to "extend our skills across as wide a spectrum of society as possible" (Eberhard, 1968, p. 38) to meet our environmental and social responsibilities. The best tool at our disposal may be research, which has universal credibility and support. As academics, it is our responsibility to continue to challenge and explore the relationship between 'knowing' and 'doing' in research, design, teaching, and service.

\footnotetext{
${ }^{6}$ See Milburn et al. (2001) for additional information on the research attitudes and behaviors of educators in landscape architecture.
} 


\section{References}

Armstrong, H., 1999. Design studios as research: an emerging paradigm for landscape architecture. Landscape Rev. 5 (2), $5-25$.

Baron, R.M., 1981. The design studio as theater of investigation. In: Comerio, M.C., Chusid, J.M. (Eds.), Proceedings of the 69th Annual Meeting of the Association of Collegiate Schools of Architecture on Teaching Architecture. Association of Collegiate Schools of Architecture, Washington, DC, pp. 220-225.

Benson, J.F., 1998. On research, scholarship and design in landscape architecture. Landscape Res. 23 (2), $198-204$.

Bowring, J., 1999. Editorial: the issue of the refereed studio. Landscape Rev. 5 (2), 1-4.

Boyer, E.L., 1990. Scholarship Reconsidered: Priorities of the Professoriate. The Carnegie Foundation for the Advancement of Teaching, Princeton, NJ.

Boyer, E.L., Mitgang, L.D., 1996. Building Community: A New Future for Architecture Education and Practice. The Carnegie Foundation for the Advancement of Teaching, Princeton, NJ.

Brink, L.A., 1997. Research and practice — a model for the design studio. In: Raval, S.R. (Ed.), CELA Proceedings on Building Toward Diversity. Council of Educators in Landscape Architecture, Asheville, NC, p. 26.

Chenoweth, R., 1992. Research: hype and reality. Landscape Architecture Mag. 82 (3), 47-48.

Chenoweth, R., Chidister, M., 1983. Attitudes toward research in landscape architecture: a study of the discipline. Landscape J. 2 , 98-113.

Cooper Marcus, C., Francis, M. (Eds.), 1998. People Places: Design Guidelines for Urban Open Space, 2nd ed. Nostrand Reinhold (Van), New York.

Dagenhart, R., Sawicki, D., 1992. Architecture and planning: the divergence of two fields. J. Plann. Educ. Res. 12, 1-16.

Dyck, R.G., 1994. Discipline vs. profession: a comment on the meaning of design. J. Plann. Educ. Res. 13 (2), $143-146$.

Eberhard, J.P., 1968. A humanist case for the system's approach. Am. Inst. Architects J. July, 34-38.

Edwards, B., 1987. Drawing on the Artist Within. Collins, New York.

Feldman, K.A., 1987. Research productivity and scholarly accomplishment of college teachers as related to their instructional effectiveness: a review and exploration. Res. Higher Learn. 26 (3), 227-297.

Glassick, C.E., Huber, M.T., Maeroff, G.I., 1997. Scholarship Assessed: A Special Report on Faculty Evaluation. The Carnegie Foundation for the Advancement of Teaching, Princeton, NJ.

Harris, R., 1995. The demands and principles of consultation. Plann. Quart. 117, 5-7.

Hutchings, P., Shulman, L.S., 1999. The Scholarship of Teaching: New Elaborations, New Developments, Change. September/ October, pp. 1115

Innes, J.E., 1996. Planning through consensus building. J. Am. Plann. Assoc. 62 (4), 460-472.

Kerlinger, F.N., 1986. Foundations of Behavioral Research, $3^{\text {rd }}$ ed. Holt, Rinchart \& Winston, Fort Worth, TX.

LaGro, J.A., 1999. Research capacity: a matter of semantics? Landscape J. 18 (2), 179-186.

Magee, B., 1985. An Introduction to Karl Popper. Open Court, La Salle, IL.

McHarg, I.L., 1997. Ecology and design. In: Thompson, G.F., Steiner, F.R. (Eds.), Ecological Design and Planning. Wiley, New York, pp. 321332.

McLaughlin, R., 1991. Research in landscape architecture. In: Westphal, J. (Ed.), Proceedings of the Conference on CELA Selected Papers. Landscape Architecture Foundation, Washington, DC, pp. 234-235.

Midwinter, J.E., 1997. A question of quality. Inst. Electr. Engr. Rev. 43 (2), 66-70.

Milburn, L.S., 1999. Research on research: the application of attitude theory to research attitudes and behaviours of educators in landscape architecture. Unpublished MLA dissertation, University of Guelph, Guelph, Ont.

Milburn, L.S., Brown, R.D., Paine, C., 2001. Research on research: research attitudes and behaviors of landscape architecture faculty in North America. Landscape Urban Plann. 57, 57- 67. 
Nassauer, J.I., 1985. Bringing science to landscape architecture. In: Stoltz, R. (Ed.), Proceedings of the CELA Forum on Issues of Teaching and Instructional Development in Professional Education. Council of Educators in Landscape Architecture, University of Guelph, Guelph, Ont., pp. $41-44$

Palmer, J.F., Smardon, R.C., Arany, J., 1984. Summary of the landscape architecture research needs survey. Agora (Winter), 17-19.

Patrick, W.J., Stanley, E.C., 1996. Assessment of research quality. Res. Higher Educ. 37 (1), 23-42.

Riley, R., 1990. Editorial commentary: some thoughts on scholarship and publication. Landscape J. 9 (1), 47-50.

Riley, R., 1995. Most important questions. Landscape J. 11 (2), 160-181.

Rosenberg, A.M., 1986. An emerging paradigm for landscape architecture. Landscape J. 5 (2), 75-82.

Rosenzweig, R., 1999. The scholarship of teaching: two suggestions and one caution. Inventio: Creative Thinking About Learning and Teaching 1 (1) (http://www.doiiit.gmu.edu/Archives/feb98/royros.htm).

Rudd, E., 1988. The evaluation of the quality of research. Stud. Higher Educ. 13 (1), 45-57.

Schön, D.A., 1988. Toward a marriage of artistry and applied science in the architectural design studio. J. Architectural Educ. 41 (4), 4-10.

Selman, P., 1995. Editorial: reflecting on practice. Landscape Res. 20 (2), 49.

Selman, P., 1998. Landscape design as research: an emerging debate. Landscape Res. 23 (2), 195-196.

Shulman, L.S., 1995. Course anatomy: the dissection and analysis of knowledge through teaching. In: Hutchings, P. (Ed.), The Course Portfolio: How Faculty can Examine their Teaching to Advance Practice and Improve Student Learning. American Association for Higher Education, Washington, DC.

Steinitz, C., 1995. Design is a verb design is a noun. Landscape J. 14 (2), 188-200.

Steinitz, C., 1998. The shape of things to come? Landscape Architecture 88 (1), 62-67.

Thompson, I.H., 1998. Environmental ethics and the development of landscape architectural theory. Landscape Res. 23 (2), $175-194$.

Thwaites, K., 1998. Landscape design as research: an exploration. Landscape Res. 23 (2), 196-198.

Tschumi, B., 1990. Questions of Space. The Architectural Association Press, London, England.

Vidler, A., 1992. History, theory and criticism. Lotus 72, 130-133.

Ward, S., 1999. A framework for incorporating the prevention of infectious disease transmission into the landscape design process. Unpublished MLA dissertation, University of Guelph, Guelph, Ont.

Zuckerman, H., Merton, R.K., 1971. Patterns of evaluation in science: institutionalisation, structure and functions of the referee system. Minerva $9,66-100$. 